Tabelle 1. Hemmung proteolytischer Fermente durch Monojodessigsäure

\begin{tabular}{c|c|c|c}
\hline $\begin{array}{c}\text { Gelatine spaltendes } \\
\text { Kathepsin }\end{array}$ & $\mathrm{p}_{\mathrm{H}} \begin{array}{c}\text { Monojodessig- } \\
\text { säureknzen- } \\
\text { tration für } 50 \% \\
\text { Hemmung }\end{array}$ & $\begin{array}{c}\text { Grenzen des } \\
\text { Mutungsbereiches } \\
\text { für } P=0,05\end{array}$ \\
\hline $\begin{array}{c}\text { Rohextrakt aus der Leber } \\
\text { Gereinigtes Ferment } \\
(1: 100)\end{array} \quad\left\{\begin{array}{c|c|c}4,0 \\
4,0 & 1,74 \cdot 10^{-6} \mathrm{~m} & 1,97 \text { bis } 1,57 \cdot 10^{-6} \mathrm{~m} \\
5,0 & 3,21 \cdot 10^{-6} \mathrm{~m} & 1,51 \text { bis } 1,07 \cdot 10^{-6} \mathrm{~m} \\
6,0 & 9,67 \cdot 10^{-6} \mathrm{~m} & 3,66 \text { bis } 2,79 \cdot 10^{-6} \mathrm{~m} \\
10,87 \text { bis } 8,16 \cdot 10^{-6} \mathrm{~m}\end{array}\right.$
\end{tabular}

aus Milz, Leber, Thymus und Niere ergeben dieselben Werte. Das gereinigte Ferment ist etwas empfindlicher. Es sei darauf hingewiesen, daß bei den Fermentansätzen des gereinigten $\mathrm{GE}$ Cystein von $0,005 \mathrm{~m}$ zugegen ist. Die Reaktionsfähigkeit der Ferment-SH-Gruppe gegenüber MES ist offenbar so stark, daß das in großem Uberschuß vorliegende Cystein die MES nicht irreversibel abzubinden vermag. Ähnliches beobachteten GREENBAUM und FrUTON ${ }^{4}$ ) an der Hemmung des Kathepsin B durch Jodacetamid.

Die Hemmung des GE ist $\mathrm{p}_{\boldsymbol{H}}$-abhängig. Bei höheren $\mathrm{p}_{\mathrm{H}}$-Werten wird es gegen MES unempfindlicher. Man könnto annehmen, daß im sauren Bereich also die Enzym-SH-Gruppe stärker und schnelier mit der MES reagiert. Ein entsprechender Modellversuch zeigte jedoch ein gegenteiliges Verhalten. Die Reaktion: Cysteamin + MES besitzt bei pu 7,0 die Geschwindigkeitskonstante $k_{370}=12,35$, bei prI $6,5=0,98$ und bei $6,0=0,074$ [Methodik der Messung bei ${ }^{5}$ ]]. Die $\mathrm{PF}_{\mathrm{F}}$ Abhängigkeit der Fermenthemmung läßt sich jedoch dadurch erklären, da.3 bei höheren $p_{H^{-}}$-Werten das zugegebene Cystein bzw. die im Rohextrakt vorhandenen SH-Gruppen stärker mit der MES reagieren als bei niedrigen und dadurch einen Teil der MES abbinden. Die Reaktion: Enzym-SH-Gruppe + MES verläuft vermutlich unabhängig vom $p_{H}-$ Wert.

Unsere Ergebnisse zeigen, daß bei einer Vergiftung eines Organismus durch MES neben der Hemmung des Gärungsstoffwechsels anch die Störung anderer Enzyme zu beachten ist. Bei einer chronischen MES-Vergiftung bei Ratten haben wir eine Atrophie von Milz und Thymus beobachtet ${ }^{6}$ ). Möglicherweise wird diese auch durch die Störung von Fermenten aus dem Eiweißstoffwechsel hervorgerufen.

Herrn Professor Holzer danke ich für einige wertvolle Hinweise.

Biophysikalische Abteilung des Heiligenberg-Instituts, Heiligenberg (Baden). (Leitung: Prof. Dr. H. LANGENDORFF)

Eingegangen am 2. November 1957

U. HAGEN

1) HAGEx, U.: Z. Naturforsch, 12b, 546 (1957). - Naturwiss 44, 402 (1957) - . 2) SCHäpFNER, A., 11. M. TRUELTE: Biochem. Z. 315, 391 (1943). - Maschmann, E., u. E. Hedmert: Hoppe-Sevlers Z. $\left.219,99(1933) .{ }^{-3}\right)$ HoLZER, H.: Medizinische 1956, 576 . Z. $219,99(1933) .{ }^{3}$ ) Holzer, H.: Medizinische 1956, $576 .-$
4) Grentaum, L. M., u. J.S. Fruton: J. of Biol. Chem. 226, 173 (1957). - 5) HAGEN, U.: Arzneimittel-Forsch. 6, 384 (1956). 6) Koch, R., u. U. HAGEN: Arch. exp. Path. u. Pharmakol, 228, 227 (1956).

\section{Trace Element Content of Milk in Indian Cattle}

During investigations on the trace element content of the forage and their soils in Western India, it was observed that the cattle were unhealthy and suffered from nutritional deficiencies. IYER and SATYANARAYAN ${ }^{2}$ ) found that except for manganese and cobalt, the forage is extremely poor in other trace elements like iron, zinc, molybdenum, boron and copper. Though millions of poor Indians cannot afford milk, literature showed that no work has been done on the trace element content of milk in Indian cattle in spite of the importance and urgency of the problem. Preliminary studies were, therefore, undertaken to determine the trace element status of milk in Indian cattle.

Method. Samples of milk from six healthy and unhealthy cows from Talegaon, a principal grassland centre of Western India were collected in polyethylene containers. The organic constituents were destroyed with a mixture of sulphuric, nitric and perchloric acids. The ash was taken up in dilute $\mathrm{HCl}$. Iron was determined with ortho-phenanthroline, copper with sodium diethyldithiocarbamate, zinc with dithizone, manganese with periodate, cobalt with nitroso-R-salt, molybdenum with dithiol, boron with quinalizarin and iodine with sodium thiosulphate. Colour intensities of unknowns and blanks were compared with those of standards in an absorptiometer.
Results and discussion. Table 1 clearly brings out the poor status of trace elements in the milk of Indian cattle. These values when compared to the normal range of concentration of various trace elements in cows' milk as given by UNDERWOOD ${ }^{5}$ are very low and the trace constituents of even healthy cows are far poorer as compared to the values of other workers ${ }^{4},{ }^{5}$ ).

Table 1. Average amounts of various trace elements in the milk of healthy and unhealthy cows (in micrograms per liter)

\begin{tabular}{|c|c|c|c|c|c|c|c|c|}
\hline Type of Cattle & 光 & $\begin{array}{l}\vec{H} \\
\stackrel{7}{F}\end{array}$ & 岁 & 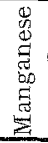 & 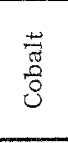 & 8 & 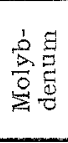 & 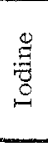 \\
\hline $\begin{array}{l}\text { Healthy } \\
\text { Healthy } \\
\text { Healthy } \\
\text { Unhealthy } \\
\text { Unhealthy } \\
\text { Unhealthy } \\
\text { Normal range of } \\
\text { concentration }^{5} \text { ) }\end{array}$ & $\begin{array}{c}1800 \\
1658 \\
1690 \\
980 \\
765 \\
847 \\
3000 \\
\text { to } \\
5000\end{array}$ & $\begin{array}{r}242 \\
212 \\
229 \\
101 \\
95 \\
83 \\
300 \\
\text { to } \\
600\end{array}$ & $\begin{array}{c}28 \\
23 \\
22 \\
3 \cdot 4 \\
4 \cdot 8 \\
5 \cdot 1 \\
50 \\
\text { to } \\
150\end{array}$ & $\begin{array}{l}21 \\
19 \\
18 \\
33 \\
21 \\
22 \\
20 \\
\text { to } \\
30\end{array}$ & $\begin{array}{l}1.80 \\
1.90 \\
1.92 \\
1.30 \\
1.20 \\
1.25 \\
0.4 \\
\text { to } \\
0.7\end{array}$ & $\begin{array}{l}0.21 \\
0.25 \\
0.19 \\
0.03 \\
0.06 \\
0.05 \\
0.5 \\
\text { to } \\
1.0\end{array}$ & $\begin{array}{l}0.02 \\
0.02 \\
0.02 \\
0.01 \\
0.01 \\
0.01 \\
40 \\
\text { to } \\
56\end{array}$ & $\begin{array}{l}5 \cdot 5 \\
5 \cdot 1 \\
4 \cdot 9 \\
1.9 \\
1.4 \\
2.1 \\
30 \\
\text { to } \\
70\end{array}$ \\
\hline
\end{tabular}

Our findings show that cow's milk is richer in zinc than any other trace element with iron ranking next. This is interesting because the forage is poor in zinc. The amounts of copper, iodine, molybdenum and boron are all exceedingly low and far below the average standards. The incidence of goiter and other diseases in Indians due to mineral deficiencies have been recorded by workers $\left.{ }^{3},{ }^{5}\right)$. Manganese is the only element that is present in normal concentrations in the milk of both healthy and unhealthy cows, being slightly higher in the former. Cow is the only animal species for which the cobalt content is known and its milk is exceedingly low in cobalt when the cow is consuming normal rations. ExLIS and THOMPSON ${ }^{1}$ ) report a mean value of $0.6 \gamma$ cobalt per liter of cow's milk. Our values show a higher cobalt content, probably due to the fact that the soils of Talegaon derived from basalt are rich in cobalt. Elsewhere it has been shown that the forage and grassland soils of Talegaon are poor in many trace elements ${ }^{2}$.

It is thus seen that the milk of Indian cattle is very deficient in almost all the important trace elements since the cattle are not fed regular rations but are allowed to graze freely on pastures shown to be deficient in trace elements. It is, however, possible that the deficiencies are influenced by the species of animal, stage of lactation and other factors. An indirect relationship between soils, plants and animals has been shown to exist. Further work is in progress.

The author wishes to thank Dr. Y. SATYANARAYAN for his help in analysis and for his critical reading of the manuscript.

Department of Botany, Institute of Science, Bombay, India

Eingegangen am 4. November 1957

(Miss) JAYA G. IYeR

I) ElLIS, G. H., and J. F. Trompson: Ind. Engng. Chem. Analyt. Edit. 17, 254 (1945). - ${ }^{2}$ ) IYER, J. G., and Y. SATYANARAYAN: J. Brit. Grassland Soc. (Communicated). - 3) KEHAR, N. D., and K. SaHAI: Bull. Nat. Inst. Sci. India 8, 113 (1955). 1) Monter-WilitaMs, G. W.: Trace Elements in Foods. London: Chapman \& Hall 1949. - 5) UNDERwood, E. J.: Trace Elements in Human and Animal Nutrition. New York: Academic Press 1955.

\section{Strahlenschutzversuche mit Alkoholen}

Die Einwirlsung von Röntgenstrahlen ruft in Eiweißlösungen unter geeigneten Versuchsbedingungen Trübungen hervor $\left.{ }^{1}\right), 2$, die durch verschiedene Substanzen verhindert werden können ${ }^{3}$. In den vorliegenden Versuchen wurde ge-prüft, ob auch Alkohole einen solchen Strahlenschutz ausïben. Am Ganztier sind bereits positive Ergebnisse mit Alkoholen erzielt worden $\left.\left.{ }^{4},{ }^{5}\right),{ }^{6}\right)$. Wir untersuchten Äthanol, n-Propanol, iso-Propanol und Butanol in Lösungen kristallisierten Pferdealbumins. Wir versetzten je $15 \mathrm{~cm}^{3}$ einer $0,5 \%$ igen Lösung des Albumins in 0,8\%iger NaCl-Lösung mit je $3 \mathrm{~cm}^{3}$ des Alkohols in steigender Konzentration. Die Endkonzentrationen in den Ansätzen waren 0,0001; 0,001; 0,01 und 0,1 molar. Zwei Kontrollportionen versetzten wir mit je $3 \mathrm{~cm}^{3}$ destillierten Wassers. Der $\mathrm{pH}^{-}$Wert betrug überall 6,0. Jede Portion wurde in zwei Teile geteilt, von denen der eine bestrahl wurde, während der andere als Kontrolle diente. Die Strahlendosis betrug etwa 1,5 $\cdot 10^{5} \mathrm{r}$ bei einer Röhrensparnung von $160 \mathrm{kV}$; Bestrahlungszeit 2 Std. Nach der Bestrahlung 